\title{
Kerem Quality Control Using the Quality Control Circle (QCC) Method at PT. XYZ
}

\author{
$1^{\text {st }}$ Yusita Attaqwa, $2^{\text {nd }}$ Wahyu Sidiq Saputra, $3^{\text {rd }}$ Ahmad Mustofa Khamal \\ ${ }^{1}$ Teknik Industri, Fakultas Teknik dan Rekayasa, Universitas Selamat Sri \\ ${ }^{2}$ Teknik Industri, Fakultas Teknik dan Rekayasa, Universitas Selamat Sri \\ 1yusitattaqwa2@gmail.com , ${ }^{2}$ wasidsap@gmail.com
}

\begin{abstract}
The 'kerem' production process is the earliest process of the entire process in iron casting. The brake itself is a mandatory thing in an iron foundry company because it functions as a limiter of the inner diameter of an iron casting product or more simply as a hole in iron casting products. With the analysis carried out using seven tools, it is expected to be able to obtain actual data to improve the quality of brake production, look for factors that affect brake quality, control the number of rejects, countermeasures, repairs, and standardization. The biggest problems with defects in the production of brakes are porous, broken, cracked and not full sand. From the aspect of $4 M+1 E$, the Man factor is the dominant cause of brake defects. Meanwhile, the number of rejects outside the 2.5\% AQL limit was 6 times, namely on 8 July 2021 as many as 16 pcs (AQL 2.5\% was at 10 pcs). Then on July 17, 2021 as many as 15 pcs (2.5\% AQL at 13 pcs) on July 182021 as many as 30 pcs (2.5\% AQL at 2 pcs) on July 202021 as many as 25 pcs (AQL $2.5 \%$ was at 12.63) on 27 July 2021 as many as 20 pcs (AQL 2.5\% was at 19 pcs) and finally on August 5, 2021 as many as 30 pcs (AQL $2.5 \%$ was at $12.6 \mathrm{pcs}$ ).
\end{abstract}

Keywords: quality, Kerem, Quality Control Circle (QCC)

\section{INTRODUCTION}

The kerem production process is the earliest process of the entire process in iron casting. The brake itself is a mandatory thing in an iron foundry company because it functions as a limiter of the inner diameter of an iron casting product or more simply as a hole in iron casting products.

Kerem comes from resin sand that is molded into the corebox with wind pressure that presses the sand into the corebox so that the construction is solid. Of course the corebox must be in a hot condition between 250$400^{\circ} \mathrm{C}$ which is adjusted according to the needs and the shape of the brake itself. A good brake is a kerem that must comply with standards both visually, dimensions and color.

The kerem is placed in the coresetter and then entered into the molding sand which will then proceed to the casting process. Molding sand itself is designed as a barrier to the outer diameter of the product which is heat-resistant. The liquid will be poured into the mold, where the molten iron fills the empty space between the brake and the molding sand.

In connection with the quality of the brakes produced received complaints, the authors conducted an analysis by looking for various factors that affect the quality of the brakes. This is carried out to improve the quality of production, reduce the number of rejects, reduce material losses, and so that the supply to the molding department can be met as needed based on the casting schedule that has been made.

Every day, the kerem department prints various types of kerem which are sometimes not the same every day. There is one type of kerem that lasts only a few hours because only a few products are ordered. However, there are several types of brakes that can last up to one month due to large orders or because the cycle time for making brakes must be long.

With the analysis carried out using seven tools, it is expected to be able to obtain actual data to improve the quality of brake production, look for factors that affect brake quality, control the number of rejects, countermeasures, repairs, and standardization.

\section{RESEARCH METHODS}

Quality control is the use of techniques and activities to achieve, maintain and improve the quality of a product or service. In other words, quality control is an effort to maintain and improve the quality of the products produced, so that they are in accordance with the product specifications that have been set based on the policy of the company's leadership (Pavletic et al, 2008).

According to Antony et al. (2000) (cited in Ariani, 2004) there are several benefits of quality control, namely:

1. Availability of information for employees if they will improve the process.

2. Helping employees to separate common causes and special causes of errors.

3. Availability of common language in process performance for various parties.

4. Eliminate deviations due to special causes to achieve better consistency and performance.

5. Better understanding of the process.

6. Significant reduction of time in quality problem resolution.

7. Reducing the cost of disposing of defective products, rework on defective products, reinspection, and so on.

8. Better communication with customers about the product's ability to meet customer specifications. 
International Journal of Computer and Information System (IJCIS)

Peer Reviewed - International Journal

Vol : Vol. 02, Issue 03, August 2021

e-ISSN : 2745-9659

https://ijcis.net/index.php/ijcis/index

9. Make the organization more oriented to statistical data rather than just assumptions.

10. Process improvement so that product quality is better, costs are lower, and productivity is increased.

Quality control is aimed at making better use of all assets owned by the company/institution, especially its human resources, in order to improve quality in a broad sense.

Kerem (core) is a tool used to produce cavities or internal features that cannot be formed using patterns in the sand casting molding process. Kerems are usually made using sand, but some processes also use permanent brakes made of metal. (Sand casting Wikipedia)

When the sand casting process is complete and at the appropriate moisture content, the mold containing the brake is then positioned to be filled with a molten metal such as iron, steel, bronze, brass, aluminum, magnesium alloy, or various metal alloys, including lead, tin, and zinc. . After being filled with molten metal the mold is set aside until the metal has cooled enough and become strong.

After the casting process, the brakes are broken by shooting and threshing so that they are removed from the casting. The casting results can be stronger when compressing the surface by firing peening so that it is resistant to forging and can smooth the rough casting surface. And when the casting results need to be dimensionally precise, various machining operations such as milling and drilling processes can be performed to complete critical casting areas.

This research was conducted at PT XYZ City S. PT $\mathrm{XYZ}$ is a metal casting factory with ductile material located in City S, the capital city of Province J, about $450 \mathrm{~km}$ from Jakarta, the capital city of Indonesia. Strategically located in an industrial area and only 18 $\mathrm{km}$ to the nearest port, TM Port.

PT XYZ is one of the companies that are members of the ABC Group, which has been known for its malleable iron pipe fittings for more than 30 years. Together with PT XYZ, the company concentrates on ductile iron products for both domestic and international markets.

This research was carried out on April 5, 2021 to May 5, 2021, starting from the planning and title selection stages to managing research results.

\section{Data Collection Techniques}

a. Primary Data, data collection is done through direct observation or field surveys and direct interviews. b. Secondary Data, data collection is obtained from production reports

\section{Quality Control Circle (QCC) Method}

Quality Control Circle is to discuss problems that occur in the company and provide recommendations for solutions to solving these problems to the Management. The problems discussed are problems related to work such as Product, Cost, Time, Inventory, Seven Quality Control Tools (QC Seven Tools) QC Seven Tools are 7 (seven) basic tools used to solve problems faced by production, especially on problems related to quality.

\section{The seven quality control tools are:}

a. Check Sheet

Check Sheet according to Nasution (2010) is a tool used to calculate how often an event is repeated. Check Sheets can record data easily and simply so as to minimize the possibility of errors that occur during data collection. The check sheet is in the form of a form designed to record data so that the note taker simply marks the available columns (Heizer and Render, 2016).

b. Pareto chart

A Pareto chart is a bar graph that shows problems in order of number of occurrences. The order starts from the number of problems that occur the most to the problems with the least frequency of occurrence. In the Graph, it is shown by the highest bar graph (far left) to the lowest graph (far right).

\section{c. Cause-Effect Diagram}

Fishbone diagram is one of the methods used to improve quality. This diagram is often called a cause-andeffect diagram or cause effect diagram that uses verbal data (non-numerical) or qualitative data. It is said to be a fishbone diagram because it is shaped like a fishbone with the muzzle of the head facing to the right. This diagram will show an impact or effect of a problem, with various causes. The effect or effect is written as the muzzle of the head. While the fish bones are filled with causes according to the approach to the problem.

d. histogram

Histogram is a tool that helps us to find variations. According to Vincent Gaspersz, histogram is a portrait that shows the distribution of measurements and the frequency of each measurement.

\section{e. Map of Control (Control Chart)}

Control Chart is to determine whether each point on the chart is normal or abnormal and can detect changes in the process from which the data is collected, so each point on the chart should indicate quickly from which process the data was taken.

f. Scatter Diagram (Scatter Diagram)

Scatter Diagram is a tool that serves to test how strong the relationship between 2 variables and determine the type of relationship. The relationship can be a positive relationship, a negative relationship or no relationship at 
International Journal of Computer and Information System (IJCIS)

Peer Reviewed - International Journal

Vol : Vol. 02, Issue 03, August 2021

e-ISSN : 2745-9659

https://ijcis.net/index.php/ijcis/index

all. The shape of the Scatter Diagram is a graphical representation consisting of a set of points from the value of a pair of variables (Variable X and Variable Y).

g. stats

Stratification in quality control is the division and grouping of data into smaller categories and have the same characteristics. The purpose of using this stratification is to identify the causal factors in a problem.

\section{ANALYSIS AND DISCUSSION}

\section{Data Collection Process}

Before starting the job, the operator must take a paper check sheet to fill out. Every shoot that enters the corebox and becomes a brake, it must be written whether the result is okay or reject. The data collection process is taken from the check sheet provided and filled in by the operator. In addition to filling out the check sheet, after each shift the head of work also fills out the available recapitulation book, making it easier for the data collection process.

The data taken comes from the recapitulation book of the results of the Ka.Shift Agung group for the period from 5 July 2021 to d. August 5, 2021. The data is the result of the production of automatic brake machines and does not include data from manual brake machines. This is because when the night shift the manual brake machine is off.

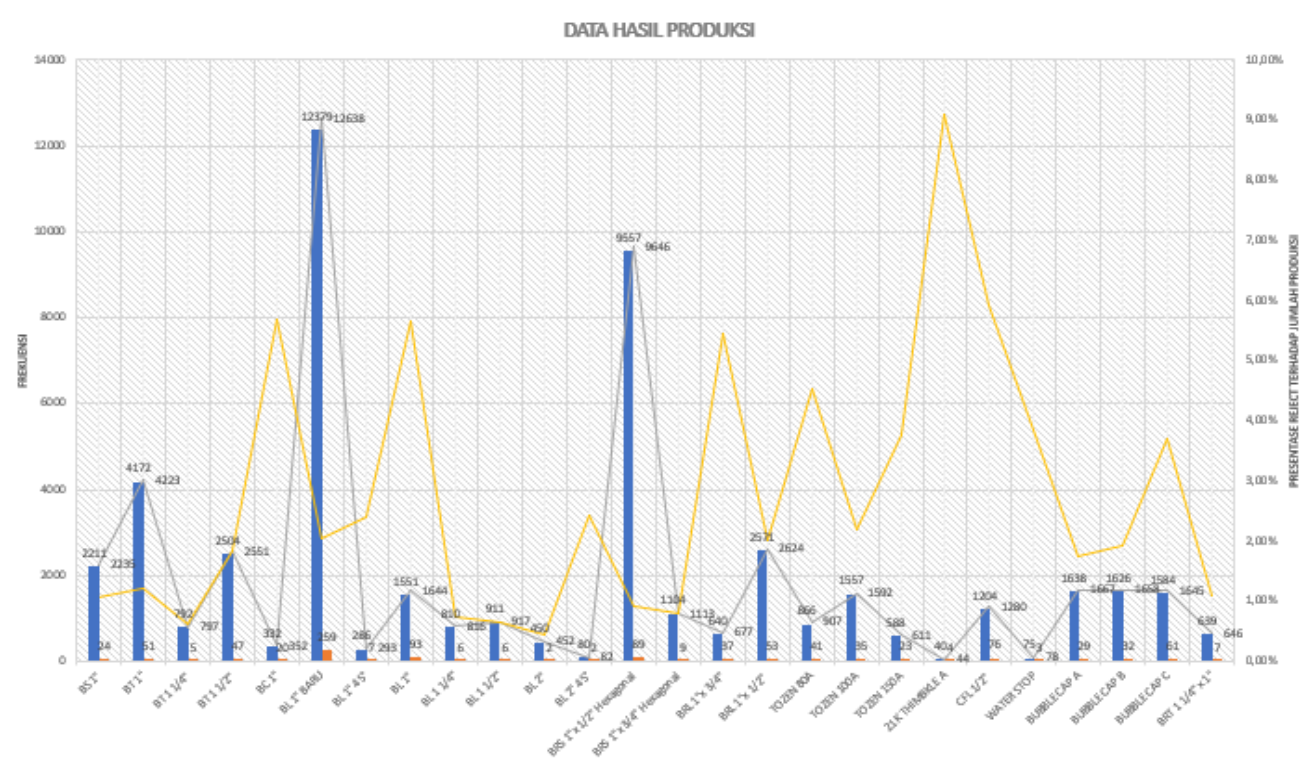

Figure 1. Graph of Kerem Production Results Data Source: Research Data, 2021

\section{Data processing}

In table 1. it can be concluded that the frequency of rejects mostly occurs in the type of goods BL 1 " New ABC. The number of rejects of 259 pcs is the highest compared to other types of goods. Because not all types of goods are produced every day, and the type of goods BL 1" ABC New produced 20 times is also the most dominant type of goods. So the author takes the type of goods BL 1 "New ABC to be applied with the Quality Control Circle method. 
International Journal of Computer and Information System (IJCIS)

Peer Reviewed - International Journal

Vol : Vol. 02, Issue 03, August 2021

e-ISSN : 2745-9659

https://ijcis.net/index.php/ijcis/index

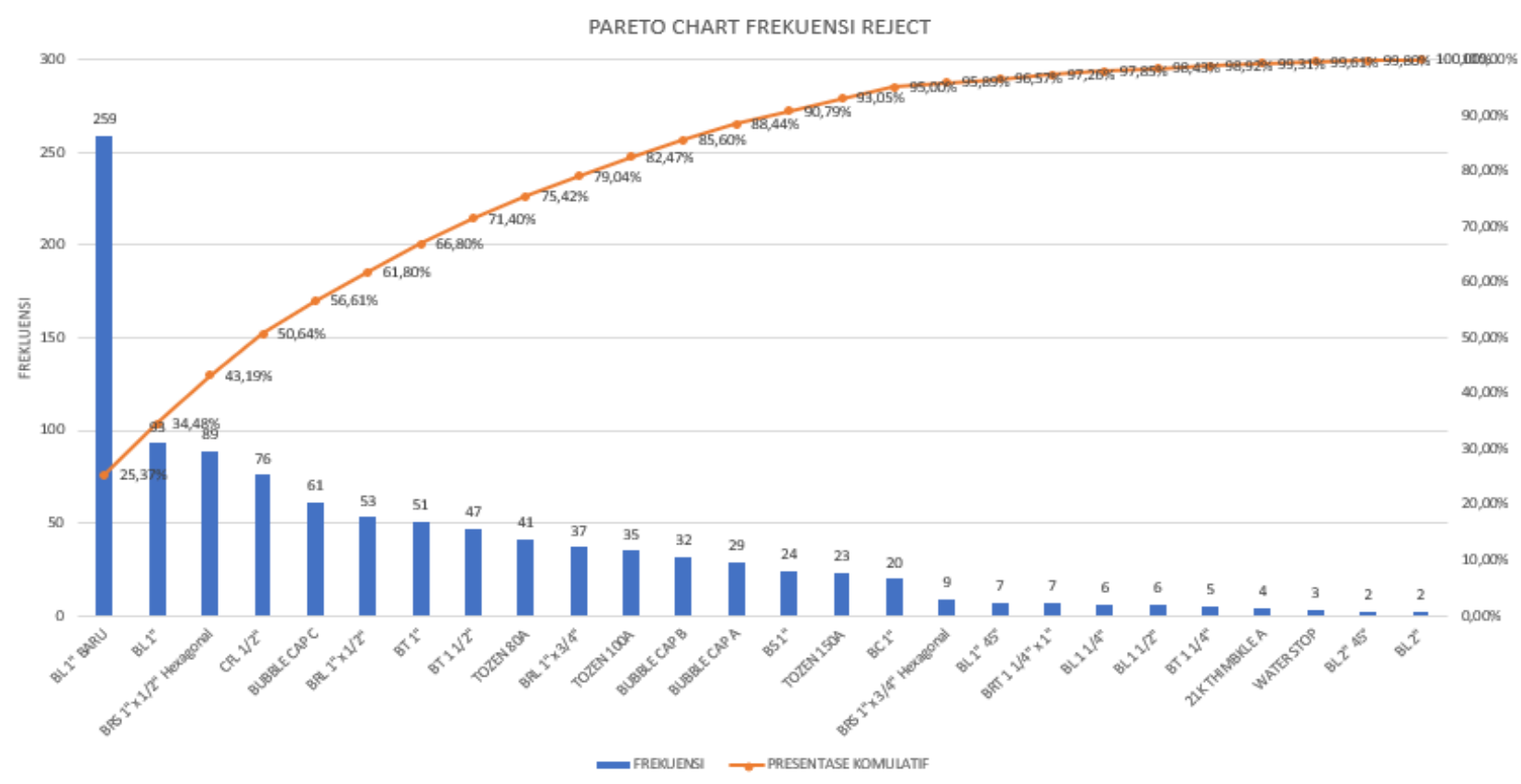

Figure 2. Pareto Chart of Production Results

Source: Research Data, 2021

\section{Determining the Dominant Reject Factor with Pareto Charts}

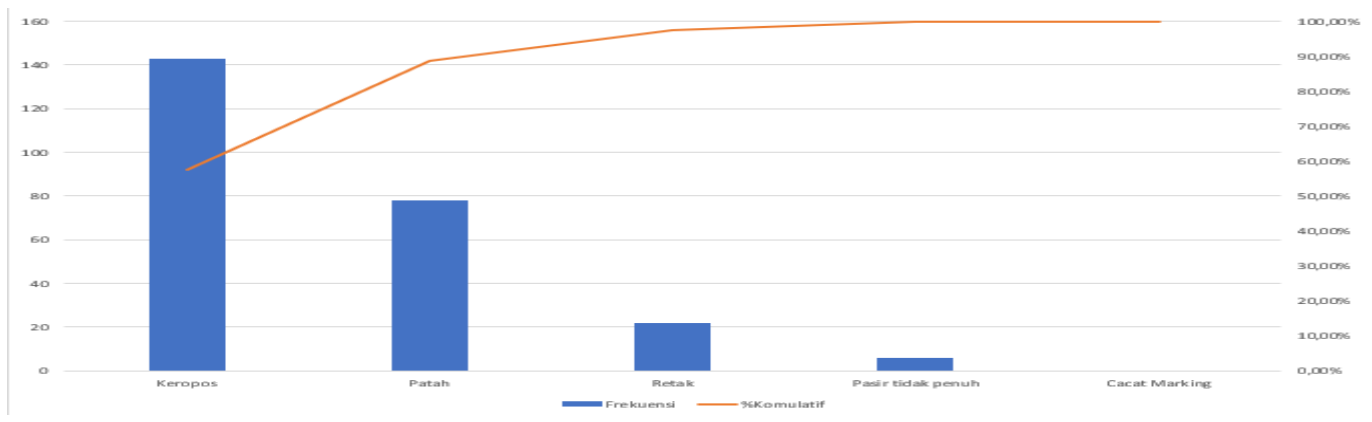

Figure 3. Pareto Chart Factors That Cause Reject Source: Research Data, 2021

From Figure 3 above, it can be read that the dominant cause of the reject factor for the BL 1" ABC Baru kerem is porous with a total of 143 pcs or $57.43 \%$. The second cause of brake defects was broken with a total of 78 pcs or $31.33 \%$ (communal $88.76 \%$ ). Third, there are 22 cracks or $8.84 \% \quad(97.59 \%$ cumulative) and 6 pcs of incomplete sand or $2.41 \%$ (100\% cumulative). As for the marking defect factor, it is 0 pcs or $0 \%$ because the new BL 1 " ABC brakes do not have markings.

\begin{tabular}{|l|r|}
\hline Rata-rata & 15,47 \\
\hline Standar deviasi & 4,52 \\
\hline Upper Control Limit & 29,02 \\
\hline Lower Control Limit & 1,92 \\
\hline
\end{tabular}

\section{Data Calculation Using Control Map u}

The process of compiling the control chart is done by calculating the proportion of each data per day. Control Map $\mathrm{u}$ is used when the amount of production each day is not constant. In using this u chart formula, the maximum number of rejects uses AQL (Acceptance Quality Limit) 2.5\%. AQL 2.5\% is applied with the ratio of the number of rejects divided by the total production results okay.

Table 1. Value of Formula Full Map u Source: Research Data, 2021 


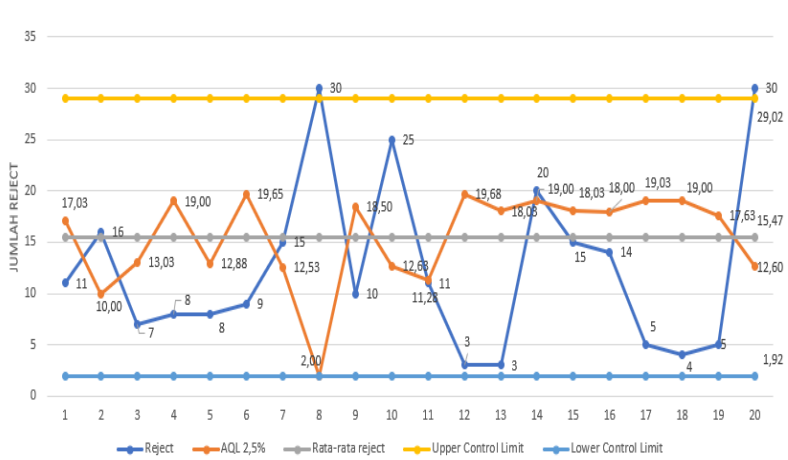

Figure 4. Reject Control Map for New BL 1" ABC GoodsSumber : Data Penelitian, 2021

From Figure 4. it can be concluded that the number of rejects for $\mathrm{BL} 1$ " $\mathrm{ABC}$ Baru goods is within the control limits. However, there were two total rejects that were above the Upper Control Limit, namely on July 18, 2021 and August 5, 2021. Both were 30 pcs, while the Upper Control Limit was at 29.02.

Meanwhile, the number of rejects outside the $2.5 \%$ AQL limit was 6 times, namely on 8 July 2021 as many as 16 pcs (AQL $2.5 \%$ was at $10 \mathrm{pcs}$ ). Then on July 17,2021 as many as 15 pcs (2.5\% AQL at 13 pcs) on July 182021 as many as 30 pcs $(2.5 \%$ AQL at 2 pcs) on July 202021 as many as 25 pcs (AQL $2.5 \%$ was at 12.63) on 27 July 2021 as many as 20 pcs (AQL $2.5 \%$ was at 19 pcs) and finally on August 5, 2021 as many as 30 pcs (AQL 2.5\% was at 12.6 pcs).

\section{Determining the Correlation with the Scatter Diagram}

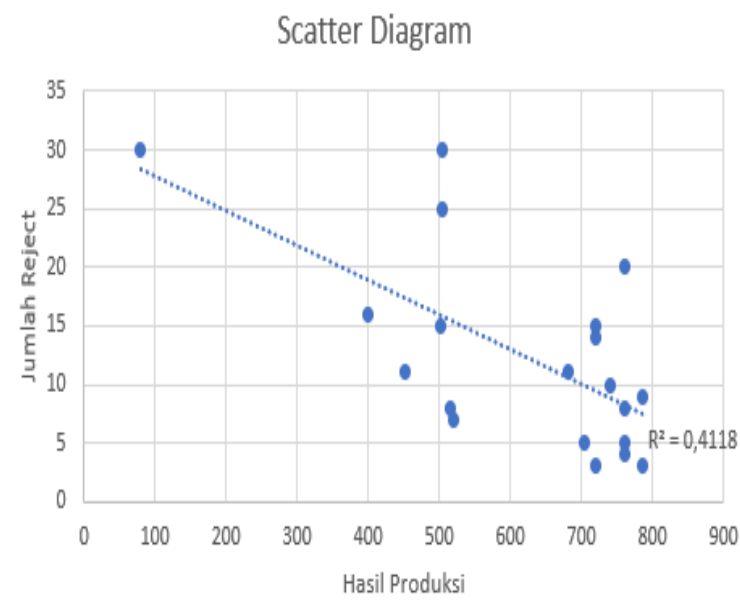

Figure 4. Determining the Correlation with the Scatter Diagram

Source: Research Data, 2021

From Figure 4. it can be concluded that the correlation/relationship between variable $\mathrm{x}$ (amount of production) and variable y (number of rejects) is very weak negative. This can be seen visually from the scatter plot which tends to point downwards. The Trendline line also confirms the correlation between the two. The correlation value $=0.4118$ (close to the value 0 ) indicates that the correlation of the two variables is very weak negative.

From the value and visual image of the scatter plot, it can be concluded that the number of rejects is inversely proportional to the number of production results. The more the number of production, the lower the percentage of the number of rejects. This is because the more we produce, of course we better understand the characteristics of the machine and what kind of machine settings must be applied in order to reduce the number of existing rejects.

\section{Factors of Production Result Problems with Cause-and-Effect Diagrams}

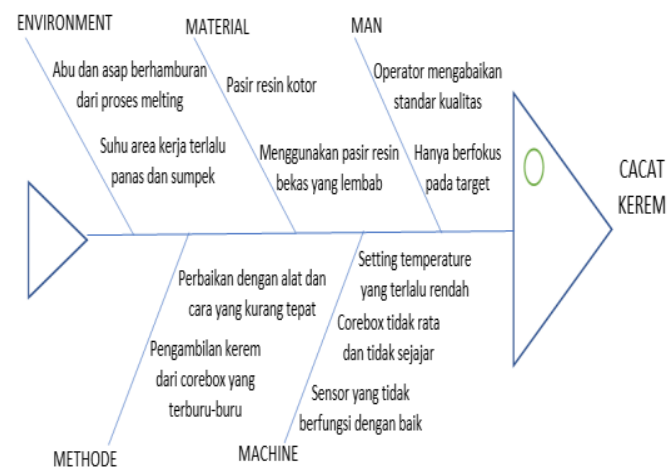

Figure 5. Fishbone Diagram/Cause-Effect Diagram Source: Research Data, 2021

From the picture above shows the causes and effects that arise from the various problems that exist. The data was taken by conducting interviews with operators (OP) totaling 6 people. Each operator gave a response by giving a score of 1-3 in each problem.

The result is that the Human factor is the dominant factor that affects the quality in the production process with a score of 18 in the cause column for the two existing causes. Then on the Machine factor, the second cause column, because the corebox is not parallel also has a score of 18. This means that the six operators agree that the misaligned corebox is also very influential in the production process. The misaligned corebox automatically creates dimensionally flawed production results.

\section{Countermeasures and Standardization}

Given the various factors that cause rejects and the causal relationship that occurs, here are some countermeasures taken to improve the quality of the production.

a. Form for corebox installation 
This process is carried out by bringing the brakes to the dimension QC room. If the brakes meet the standards, the production process will be carried out according to the SPK (Work Order).

b. Form quality

This form is given to Visual QC in the brake department which aims to continuously monitor production results during the production process. QC will continue to go around checking brakes to avoid brake defects both visually, color and dimensions.

c. Standardize the number of goods per container Standardization aims for operators to generalize the amount of production into the container. Apart from the similarity in terms of the number of each container, too many brakes are also difficult when the container is unloaded because the weight is too heavy. In addition to the above, this standardization also aims to reduce the risk of brake brakes breaking in containers (because they are too many and too heavy), simplify calculations when reporting, both for operators and admins.

d. Kerem color standardization

Color standardization is displayed on the board based on the kerem charred, standard and raw colors. This standard is given in the hope that the operator understands and applies the requirements for the production of brakes based on color.

e. Provision of SPK (Work Order)

The provision of SPK only revolves around the target of each type of goods in each shift. Previously, SPK did not limit the number of shifts, but the number each day, so that in shift 3 they often ran out of goods because the SPK ran out. This resulted in uneven production results in shifts 1 and 2 . In addition, the quality was also neglected because the operators of shift 1 and shift 2 focused on as many results as possible. The new SPK applies the amount of production only around the target number for each type of goods. This standardization is expected to improve the quality of production because operators do not need to pursue large quantities of production.

\section{CONCLUSION}

1. The biggest problem of defects in the production of kerem is porous, broken, cracked and not full sand.

2. Based on the control chart, daily kerem rejects are under control although there are some that are out of control but not up to a difference of 2 pcs.

3. The more production of a type of goods, the less total rejects will be because the operator will understand the characteristics of the machine and what settings should be applied to minimize the number of rejects.
4. From the aspect of $4 M+1 E$, the Man factor is the dominant cause of brake defects. Because operators are too focused on pursuing targets so they ignore the quality of their products. However, the Machine factor, namely the uneven or misaligned corebox, has the same value in affecting the quality.

5. Various countermeasures and standardization are applied to prevent brake defects from installing coreboxes to the brake distribution process to the next department.

Based on the results of the research conducted, the following suggestions can be given:

1. Checking after installing the corebox as well as trialling some of its production to ensure that the production meets quality standards both visually, dimensions and color.

2. Conduct socialization to operators so that they work with enthusiasm to fulfill production without neglecting the quality of their products.

3. Operators are expected to carry out independent and periodic checks on their production results to prevent defective production results as early as possible.

4. QC must continue to control and check the quality of the kerem production on a regular basis to avoid production defects if there are other factors that cause defects in the production results.

5. Using methods and tools that are appropriate for their function.

\section{REFERENCES}

[1.] Yohanto, Roni. 2008. Laporan Kerja Praktek Proses Produksi dan Pengendalian Kualitas. Kerja Praktek. Universitas Indonusa Esa Unggul, Jakarta.

[2.] Sulaeman. 2014. Analisa Pengendalian Kualitas untuk Mengurangi Produk Cacat Speedometer Mobil dengan Menggunakan Metode QCC di PT INS. Jurnal PASTI. Vol VIII. No. 1, 71-95

[3.] Wikipedia. Sand Casting. Sand casting - Wikipedia. Diakses tanggal 23 September 2021. IPQI. Metode QCC dalam Pengendalian Kualitas.

[4.] Pengertian Gugus Kendali Mutu (GKM) / Quality Control Circle (QCC) - IPQI Diakses tanggal 7 September 2021.

[5.] Sevice, AQI. AQL 2,5\%. What does AQL 2.5 Mean in Quality Inspection? | AQL Standard (aqiservice.com) Diakses tanggal 25 September 2021.

[6.] Haryadi. 2018. Analisa Pengendalian Kualitas untuk Mengurangi Jumlah Cacat Produk Dari Proses Cutting dengan Metode Quality Control Circle (QCC) Pada PT. Toyota Boshoku Indonesia (TBINA). Kerja Praktek. Universitas Mercu Buana, Jakarta.

[7.] Jannah, A. M., Muqorobin, M., \& Widiyanto, W. W. (2020). Analysis Of Kids Garden Dapodic Application System. International Journal of Computer and Information System (IJCIS), 1(3), 55-58. 
International Journal of Computer and Information System (IJCIS)

Peer Reviewed - International Journal

Vol : Vol. 02, Issue 03, August 2021

e-ISSN : 2745-9659

https://ijcis.net/index.php/ijcis/index

[8.] Jannah, N. F., \& Muqorobin, M. (2021). Analysis Of Kasir Applications In Sales Management Information Systems at ASRI Store. International Journal of Computer and Information System (IJCIS), 2(2), 40-44.

[9.] Santoso, L. P., Muqorobin, M., \& Fatkhurrochman, F. (2020). Online Analysis System of Application of Partners for Land Asrocument Officers of Sukoharjo District. International Journal of Computer and Information System (IJCIS), 1(3), 59-61. 